\title{
The new pharmacovigilance legislation and impact on observational studies
}

\author{
Sinem Ezgi Gülmez
}

\begin{abstract}
BACKGROUND: After the publication of the Regulation (EU) No 1235/2010 and Directive 2010/84/EU on $31^{\text {st }}$ of December 2010, the new legislation on pharmacovigilance came into operation for the better protection of public health through a further strengthened EU system for medicines safety.

REMARKS: The main changes include the new definition of adverse reactions, Eudravigilance becoming the single receipt point for all pharmacovigilance information through the EU, the Pharmacovigilance Risk Assessment Committee, and strengthened PASS/PAES, and requirement of a risk management planning for all new medicines. The possible increase in PA(E)SS may be a concern in terms of access to appropriate data and so obtaining necessary authorisations without delays.

CONCLUSION: The new legislation will provide good vigilance practice standards with increased transparency of pharmacovigilance data. The communication will improve with the involvement of patient and public. With better access to real-life data, better protection of public health will be ensured.
\end{abstract}

KEYWORDS: pharmacovigilance legislation, pharmacoepidemiology, observational study, regulations, European Directive

\section{INTRODUCTION}

The European Medicines Agency (EMA) recently welcome the European Union (EU) legislation on pharmacovigilance for the better protection of public health through a further strengthened EU system for medicines safety.

As a short look to the history of this new legislation, the need for the new pharmacovigilance legislation was firstly pronounced in 2004. The work then began in 2008. Two years later in 2010, European Parliament and Member States adopted the new legislation. On 31 ${ }^{\text {st }}$ of December 2010, both the Regulation (EU) No 1235/2010 and Directive 2010/84/EU were published $(1,2)$. The Member States were provided some time to adapt their national law and regulations. In July 2012, the new pharmacovigilance legislation was applied and came into operation. Briefly, the legal framework for pharmacovigilance of medicinal products for human use in the EU is given in Regulation (EC) No 726/2004 and Directive 2001/83/EC on the Community code relating to medicinal products for human use, as amended in 2010 by Regulation (EU) No 1235/ 2010 and Directive 2010/84/EU, respectively, as well as by the Commission Implementing Regulation (EU) No 520/2012 on the Performance of Pharmacovigilance Activities Provided for in Regulation (EC) No 726/2004 and Directive 2001/83/EC. The aforementioned amending legislation of 2010, together with the related implementing
AFFILIATIONS

1Université Bordeaux Segalen, Pharmacologie, Bordeaux, Fransa

\section{CORRESPONDENCE}

Sinem Ezgi Gülmez

E-mail:

sinemezgi.gulmez@ u-bordeaux2.fr

Received:

28.01.2013

Revision:

28.01.2013

Accepted:

11.02.2013 
Regulation, is commonly referred to as the new pharmacovigilance legislation in the EU. It was the outcome of a major review of the current pharmacovigilance system in the EU conducted by the European Commission (EC), followed by a formal law-making process in the Council and European Parliament.

This paper aims firstly to summarise the main changes and highlights of the new pharmacovigilance legislation in the EU, then to share an opinion on its impact particularly on observational studies.

\section{Main changes and highlights at a glance}

The main changes and highlights of the new pharmacovigilance legislation can be summarized as follows:

1) New definition of Adverse Reactions (Regulation (EU) No 1235/2010 Art. 1):

An adverse reaction (AR) is newly defined as " $a$ response to a medicinal product which is noxious and unintended". The Regulation removed "dose" from the previous definition, because noxious and unintended effects result from the authorised use of a medicinal product at normal doses, as well as from medication errors and uses outside the terms of the marketing authorisation (MA), including the misuse and abuse of a medicinal product" (Recital 5). Therefore, this includes also reporting of adverse drug reactions (ADRs) not only in normal conditions of use, but also from uses outside terms of MA (misuse and abuse, medication error, overdose, and occupational exposure). Although there is not a definition in the new pharmacovigilance legislation, the Good Vigilance Practice (GVP) defined the terms overdose, misuse, abuse, medication error, and occupational exposure. An important note is that all medication errors that result in an ADR are to be reported.

\section{2) Eudravigilance Database}

Eudravigilance is the database collecting ADRs at the EU level (3). Eudravigilance now became the cornerstone of the European pharmacovigilance systems and the receipt point for all pharmacovigilance information within the EU. Member States have to set up national pharmacovigilance websites to provide information on medicinal products and their proven side effects. These portals will be linked to the EU Eudravigilance, which will contain further detailed information on all medicines. Also, consumers will be encouraged to report suspected side effects to these websites.

The Eudravigilance database will be fully accessible to the Member States, the EMA and the EC. An access to an appropriate extent is granted to marketing authorization holders (MAH), physicians, and the public (Regulation (EU) No 1235/2010 Art. 57(f) $(1,4)$.

Patients will have to be made aware of the possibility of reporting directly to the health authorities (Regulation (EU) No 1235/2010 Art. 59 (1e)). The Commission will draw up a list of intensely monitored medicinal products, which have to bear a black symbol (Regulation (EU) No 1235/2010 Art. 23). Concerning the reporting by pharmaceutical companies, the rules on reporting ADRs by companies is set to become less burdensome, but stricter. The old regime required companies to include detailed descriptions of their pharmacovigilance systems when submitting MA applications, while the new legisla- tion only requires the key elements of these systems to be listed. However, this is balanced by the need to maintain a detailed file on site, which will be open to inspection by the competent authorities.

The patient information leaflet (PIL) in all EU languages shall be made available in the Eudravigilance database via the national web-portals, which have to be established by the Member States (Regulation (EU) No 1235/2010 Art. 106 (1)). The PIL will thus become a document available to the wider public. Pharmaceutical entrepreneurs could therefore refer to the national or EU web-portals in print media or the Internet.

The new definition of ARs together with the possibility for direct reporting by patients to the health authorities will probably increase the workload of the authorities.

3) The Pharmacovigilance Risk Assessment Committee (PRAC) (Regulation (EU) No 1235/2010 Recital 8)

A new scientific committee, the Pharmacovigilance Risk Assessment Committee (PRAC) has been set up within the EMA. The PRAC is the only body in charge of pharmacovigilance and risk assessment, in order to reduce duplication of roles. The aim of the EMA to establish this committee is to increase the transparency of ongoing applications for human medicines, and to provide better communication (5). This new level of transparency involves the publication of information on applications for changes to the authorised use of medicines where a change to the risk management plan (RMP) is needed. In these cases, the PRAC is required to provide advice to the CHMP on the necessary updates to the RMP. The PRAC may hold public hearings when it considers it appropriate on justified grounds, particularly with regard to the extent and seriousness of the issue. In this regard, the EMA has started publishing information on ongoing applications for extensions of indication of human medicines in the minutes of the PRAC.

4) Green Pharmacovigilance (Regulation (EU) No 1235/2010 Recital 3):

An important point to be underlined involves the environmental effects caused by residues of medicinal products for human use. The EC should report back (i.e. water and soil pollution) and enact relevant amendments to the new pharmacovigilance legislation or develop other further legislation if required.

5) Risk management planning (Regulation (EU) No 1235/2010 Recital 17):

A risk management planning (RMP) is required for all new products as well as the justified old ones. If there are concerns about the risks affecting the benefit-risk balance, a risk management system or RMP is required for an authorised product. Within this RMP, safety and efficacy studies are included. This new requirement gives another systematic role to the new PRAC.

6) a) Post authorization safety studies (PASS), Art. 21a (2)) / Post authorization efficacy studies (PAES), Art. 21a (6))

PASS is defined as "any study relating to an authorised medicinal product conducted with the aim of identifying, characterising or quantifying a safety hazard, confirming the safety profile of the medicinal product, or of measuring the effectiveness of risk management 
measures". Non-interventional PASS could be initiated, managed or financed by the MAH voluntarily or following the obligations imposed by the regulators and which involve the collection of data on suspected ARs from patients or healthcare professionals. PASS could be requested by the regulators at the first authorisation or after authorisation.

PAES are also strengthened at legal basis. If PAES is requested for the MA of the medicinal product, it concerns some aspects of the efficacy of the product identified and can be resolved only after the product has been marketed. If PAES is conducted at post-authorisation, then the understanding of the disease or the clinical methodology indicates that previous efficacy evaluations might have to be modified significantly, which creates the obligation for the MAH to provide efficacy data after the MA has been granted. Implementing measures may be adopted by the EC and scientific guidelines by the EMA.

\section{b) Periodic safety update reports (PSURs)}

Simplifications for PSURs are foreseen in form of an exception from the obligation to present PSURs for generics, wellestablished use products, registered homeopathics and traditional herbal medicinal products (Art. 107 (3)). However, the simplifications apply automatically only to products coming new into the market. For products already in the market, transitional periods apply which are in need of further clarification. Additionally, the competent authorities have the right to request PSURs in cases of "concerns relating to pharmacovigilance data". It has to be ensured that these "concerns" are clearly defined and that a common practice is applied throughout the EU.

\section{New pharmacovigilance legislation and the impact on real-life studies}

Pharmacoepidemiology is the study of the use and effects/ side effects of drugs in large numbers of people. It uses the techniques of epidemiology to study the use and the effects of drugs, and the major application is after the drug is marketed (6). The purpose of pharmacoepidemiology is to support the rational and cost-effective use of drugs in the population thereby improving health outcomes (rational use, efficacy, tolerability, effects on the population). It is the process of assessing a product's benefits and risks, and developing, implementing, and evaluating strategies to enhance the overall balance of such benefits and risks. Therefore, pharmacoepidemiology is the scientific backbone of therapeutic risk management.

The new pharmacovigilance legislation will present new opportunities for pharmacoepidemiologists. According to the new pharmacovigilance legislation, an RMP is required for all new medicines. This will result in risk planning of post-authorisation risk minimisation and data collection. There will be obviously more studies conducted by pharmaceutical companies or academicians as well as studies to be conducted at the request of the health authorities. MAHs may be subject to the requirement to conduct $\mathrm{PAS}(\mathrm{E}) \mathrm{S}$ when important questions relating to the efficacy of a product remain, when scientific advances in the understanding of the disease or in the clinical methodology would significantly change previous efficacy evaluations.

A post-authorisation study could be a clinical trial or a noninterventional study. If the PASS is a clinical trial, Directive
2001/20/EC (7) and Volume 10 of The Rules Governing Medicinal Products in the EU shall apply. But Good Pharmacovigilance Practices (GVP) Module VIII $(8,9)$ shall apply if PASS is non-interventional that is initiated, managed or financed by a MAH under obligations imposed by a national competent authority, the Agency or the Commission in accordance with Directive 2001/83/EC (Articles 21a, 22a) and Regulation (EC) No 726/2004 (Articles 10, 10a).

Many of the new requirements by the new pharmacovigilance legislation discussed above, such as RMP and PASS/PAES, will require access to appropriate data that requires relevant authorisation(s).

In non-interventional studies, patients are usually involved indirectly as data are collected from existing population databases or hospital medical records. Accessing these data should require only authorisation from the relevant data protection committee on the basis of Directive 95/46/EC (10).

The existence of Directive 95/46/EC might lead one to expect similar procedures for study approval across European countries. However, from a European post-authorisation safety study, we experienced that this was not the case (11). The Study of Acute Liver Transplant (SALT) was conducted at the request of the CHMP, which required strict timelines for the final study report. However, the difficulties in obtaining access to data for the SALT study encompassed multiple local authorities, regions and/or countries. Of the seven countries participated to the SALT (France, Greece, Ireland, Italy, Portugal, The Netherlands, United Kingdom), the regulatory processes and reply times were heterogeneous, even within the same country. Furthermore, contract negotiation times took years longer in some countries compared to others. This resulted in delays to finish the study. The potential harm to patients in real-life might occur if the patients continue to be treated with a dangerous drug that stays on the market longer than needed because of unnecessary administrative delays. Considering the possible increase in number of PASS to be conducted in line with the new requirements by the new pharmacovigilance legislation, the importance of obtaining necessary authorisations to access to data should be finalized without any delay.

\section{CONCLUSION}

The new pharmacovigilance legislation, as underlined by the European Medicines Agency (EMA), is the biggest change for human medicines and in the EU regulatory framework since 1995 , with the primary aim to strengthen and rationalise pharmacovigilance and increase patient safety. It will certainly provide good vigilance practice standards with increased transparency of pharmacovigilance data. The communication will improve with the involvement of patient and public. With better access to real-life data, better protection of public health will be ensured. Apparently the application of this new legislation and the existing Directives will take a few years to fully implement. Furthermore, complexity and disharmony in the regulatory requirements both within and across countries still need to be worked out to make compliance with requirements less expensive and time-consuming. 


\section{Yeni farmakovijilans yönergesi ve gözlemsel çalışmalar}

\section{ÖZET}

GiRiŞ: 1235/2010 sayılı yeni tüzük ve 2010/84/EU sayılı yeni farmakovijilans yönergesi, Avrupa Birliği (AB) Resmi Gazetesi'nde 31 Aralık 2010 tarihinde yayımlandıktan sonra yürürlüğe girdi. Yeni düzenlemelerle AB, halk sağlığı ve ilaç güvenliliğine daha sıkı bir takip getirmiş oldu.

GELiŞME: Yeni farmakovijilans mevzuatında göze çarpan ana değişiklikler, advers reaksiyonların yeni tanımını, Eudravijilans veritabanının tüm $\mathrm{AB}$ farmakovijilans sistemi için tek bir referans noktası haline getilirmesini, Farmakovijilans Risk Belirleme Komitesi'nin oluşturulmasını, ruhsat sonrası etkililik ve güvenlilik çalışmalarını ve tüm beşeri tıbbi ürünler için risk yönetim sistemi oluşturulmasını kapsamaktadır. Ruhsat sonrası etkililik ve güvenlilik çalışmalarında olası bir artış beklenmektedir. Ancak bu, uygun ve gerekli verilere ulaşabilmek için gerekli izinlerin gecikme olmadan alınabilmesini gerektirmektedir.

SONUÇ: Yeni farmakovijilans düzenlemeleri, iyi vijilans uygulamaları standartlarına artmış bir şeffaflık getirmektedir. Hastaların ve kamunun da katılımıyla, iletişim daha da gelişecektir. "Gerçek hayat" verilerine daha iyi ulaşılarak halk sağlığı daha iyi korunacaktır.

ANAHTAR SÖZCÜKLER: Farmakovijilans yönetmeliği, farmakoepidemiyoloji, farmakovijilans, yasal düzenlemeler

\section{REFERENCES}

1. Regulation (EU) No $1235 / 2010$ of the European Parliament and of the Council of 15 December 2010. Official Journal of the European Union dated 31.12.2010. L 348/1-16. PDF document. http://eur-lex.europa.eu/ LexUriServ/LexUriServ.do?uri=OJ:L:2010:348:0001:001 6:EN:PDF [Accessed: November 15th, 2012]

2. Directive $2010 / 84 / E U$ of the European Parliament and of the Council of 15 December 2010. Official Journal of the European Union dated 31.12.2010. L 348/74-99. PDF document. http://eur-lex.europa.eu/LexUriServ/LexUriServ.do?uri=OJ:L:2010:348:0074:0099:EN:PDF [Accessed: November 15th, 2012]

3. Eudravigilance database. http://eudravigilance.ema. europa.eu/ [Accessed: November 15th, 2012]

4. European Medicines Agency plans public access to information on side effects.http:/ / www.ema.europa.eu/ema/ index.jsp?curl=pages/news_and_events/news/2011/07/ news_detail_001299.jsp\&murl=menus/news_and events/news_and_events.jsp\&mid=WC0b01ac058004d5c1 \&jsenabled=true [Accessed: November 15th, 2012]

5. European Medicines Agency increases transparency of ongoing applications for human medicines. News, dated 07/11/2012.http://www.ema.europa.eu/ema/index. jsp?curl=pages/news_and_events/news/2012/11/ news_detail_001648.jsp\&mid=WC0b01ac058004d5c1 [Accessed: November 15th, 2012]

6. Edited by: Strom BL, Kimmel SE, Hennessy S. Pharmacoepidemiology. Fifth Edition. John Wiley \& Sons, Ltd. 2012.
7. Directive 2001/20/EC of the European Parliament and of the Council of 4 April 2001 on the approximation of the laws, regulations and administrative provisions of the Member States relating to the implementation of good clinical practice in the conduct of clinical trials on medicinal products for human use., L 121/34. Sect. 34 (2001).

8. Guideline on good pharmacovigilance practices (GVP) Module VIII - Post-authorisation safety studies. PDF document.http://www.ema.europa.eu/docs/en_GB/ document_library/Scientific_guideline/2012/06/ WC500129137.pdf [Accessed: November 15th, 2012]

9. Annex to GVP module VIII - Post-authorisation safety studies. PDF document. http://www.ema.europa. eu/docs/en_GB/document_library/Scientific_guideline/2012/06/WC500129147.pdf [Accessed: November 15th, 2012]

10. Directive 1995/46/EC of the European Parliament and of the Council of 24 October 1995 on the protection of individuals with regard to the processing of personal data and on the free movement of such data. L 281. Sect. 31 (1995).

11. Gulmez SE, Lignot-Maleyran $S$, de Vries CS, Sturkenboom M, Micon S, Hamoud F, et al. Administrative complexities for a European observational study despite directives harmonising requirements. Pharmacoepidemiol Drug Saf 2012;21:851-6. 